\title{
CELL SURFACES AND EMBRYOS: EXPRESSION OF THE F9 TERATOCARCINOMA ANTIGEN IN $T$-REGION LETHAL, OTHER LETHAL, AND NORMAL PRE-IMPLANTATION MOUSE EMBRYOS
}

\author{
ROBERT P. ERICKSON and SUSAN E. LEWIS * \\ Department of Human Genetics, Box 015, University of Michigan School of Medicine, Ann Arbor, \\ MI 48109, U.S.A.
}

(Received 30 June 1980; accepted 28 July 1980)

F9 teratocarcinoma antigen is expressed normally on embryos which are homozygous recessive for each of 4 mutations lethal in early development, including $t^{12}$. Homozygosity for two post-implantation $T$-region developmental lethal genes, $t^{\mathrm{w5}}$ and $T^{\mathrm{Or} 1}$, may alter F9 antigen expression but the results were not definitive. In addition, the time of appearance of the antigen may be affected by some of the genotypes.

\section{INTRODUCTION}

The concept that cell surfaces contain information used for communication between cells during morphogenesis is an old one. During recent decades antigens have been sought as the counterparts of such cell surface molecules. In particular, they have been found with spectacular success among lymphocytes where they have clearly been shown to be markers of differentiation (Hood et al., 1977).

There has been less direct evidence for such cell surface markers in embryogenesis. One antigen that is expressed in early embryos and which, because of its association with developmental mutants, has been reported to have a role in morphogenesis is the F9 teratocarcinoma antigen. The class of teratocarcinoma antigens which cross-react with embryos was initially found by Edidin and co-workers who raised antisera in rabbits directed against mouse teratocarcinoma (Edidin et al., 1971). Artzt and co-workers produced a syngeneic antiserum against cell lines from such a tetracarcinoma using irradiated cells from a nullipotent embryonal carcinoma cell line, F9 (Artzt et al., 1973). This antiserum (anti-F9) also reacted with preimplantation embryos and male germ line cells.

Developmental lethal mutations of the $T$-region of the mouse were reported to alter F9 antigenic reactivity (Artzt et al., 1974). This complex region on the proximal portion of chromosome 17 includes loci with effects on sperm function, chromosomal exchanges, interaction with a single dominant mutation to affect tail length, and embryonic lethality. The embryonic lethality falls into six complementation groups, each with its own characteristic stage of developmental delay. It was suggested that the structural gene for the F9 antigen was located in the $T$-region of chromosome 17 of the mouse since 1 ), twice as many sperm cells from a $+/ t^{\mathrm{w} 32}$ mouse were needed to remove a standard amount of F9 antiserum when compared to sperm from a $+/+$ mouse (Artzt et al., 1974) and 2) expression of the $\mathrm{F} 9$ antigen appeared to segregate among the progeny of crosses producing

\footnotetext{
* Present address: Research Triangle Institute, Research Triangle Park, NC 27709, U.S.A.
} 
$t^{\mathrm{w} 32} / t^{\mathrm{w} 32}$ or $t^{\mathrm{w} 5} / t^{\mathrm{w} 5}$ embryos (Kemler et al., 1976). The number of negative embryos approximated to the expected number of $t$-allele homozygotes. Originally, it was said that $t^{12}$ homozygous embryos expressed no F9 antigen. However, the Artzt group now believe that $t^{12} / t^{12}$ embryos show less F9 antigen but that 'regardless of $t$ genotype, all four-cell to morula stage embryos display at least some F9 antigen' (Marticorena et al., 1978). Since a variety of factors could cause such discrepancies, we have investigated the expression of F9 antigen in normal pre-implantation embryos and embryos homozygous for lethal mutations at a variety of loci, using three different antisera, in order to further the understanding of genetic effects on cell surfaces and early development.

\section{MATERIALS AND METHODS}

\section{Mutant mouse strains}

The mouse mutants are maintained as inbred lines and are designated: (1) $T / t^{12}$, (2) $T / t^{\mathrm{w} 5}$ (balanced lethal lines since $T / T$ and $t^{\mathrm{n}} / t^{\mathrm{n}}$ die in utero), (3) $T^{\mathrm{Or} 1} /+$, (4) $c^{\mathrm{ch}} / c^{2 \mathrm{sH}}$,

\section{TABLE 1}

Developmental lethal mutations studied

\begin{tabular}{lllll}
\hline Gene Locus & Linkage & $\begin{array}{l}\text { Developmental } \\
\text { age first }\end{array}$ & $\begin{array}{l}\text { Developmental } \\
\text { stage normal } \\
\text { morphologically } \\
\text { detectable a }\end{array}$ & $\begin{array}{l}\text { Distinguishable } \\
\text { morphology of mutant }\end{array}$ \\
& & \\
\hline
\end{tabular}

Pre-implantation lethals

$\begin{array}{llllll}c^{25} & \text { Albino } & 7 & 2 \frac{1}{2} \text { days } & \text { Morulae } & \text { Arrested at 2-6 cell stage } \\ \text { Os } & \begin{array}{l}\text { Oligo-syn- } \\ \text { dactylism }\end{array} & 8 & 4 \text { days } & \begin{array}{c}\text { Expanded or } \\ \text { hatched } \\ \text { blastocysts }\end{array} & \begin{array}{l}\text { Retarded blastocyst } \\ t^{12}\end{array} \\ \text { T-region } & 17 & 3 \frac{1}{2} \text { days } & \text { Blastocysts } & \text { Morulae }^{b}\end{array}$

Post-implantation lethals

\begin{tabular}{|c|c|c|c|c|c|}
\hline$c^{6 \mathrm{H}}$ & Albino & 7 & 7 days & $\begin{array}{l}\text { Egg cylinder with } \\
\text { primitive } \\
\text { streak }\end{array}$ & $\begin{array}{l}\text { Very retarded egg cylinder } \\
\text { and primitive streak and } \\
\text { nearly absent ecto- } \\
\text { placental cone }\end{array}$ \\
\hline$T^{0 \mathrm{r} 1}$ & $T$-region & 17 & 7 days & $\begin{array}{l}\text { Egg cylinder with } \\
\text { primitive } \\
\text { streak }\end{array}$ & $\begin{array}{l}\text { Total arrest of egg cylinder } \\
\text { only parietal yolk sac and } \\
\text { trophoblastic giant cells } \\
\text { differentiate }\end{array}$ \\
\hline$t^{\mathrm{w} 5}$ & $T$-region & 17 & 7 days & $\begin{array}{l}\text { Egg cylinder with } \\
\text { primitive } \\
\text { streak }\end{array}$ & Very similar to $T^{\text {Or } 1}$ \\
\hline
\end{tabular}

\footnotetext{
a This applies to gross identification in unfixed material. Identification can be earlier in certain histological or cytological preparations.

b Some overlap with normal embryos.
} 
(5) $c^{\mathrm{ch}} / c^{6 \mathrm{H}}$, and (6) $+/ O s$. The distinguishing characteristics of these developmental lethal mutations are given in Table 1. The first, fourth and fifth were obtained from Dr. S. Gluecksohn-Waelsch, the third from J.L. Guenet, the sixth from the Jackson Laboratory, the second from Dr. William F. Dove, and the last from Dr. R. Pedersen. Embryos were used directly from lines 4-6 without any outcrosses. Control embryos $(+/+)$ were derived from a variety of inbred strains while outcrosses of lines 1 and 2 to $\mathrm{A} / \mathrm{J}$ or $\mathrm{C} 57 \mathrm{BL} / 10 \mathrm{~J}$ produced the necessary $T /+$ and $+/ t$ types.

\section{Preparation and absorption of antisera}

$129 / \mathrm{Sv}$ mice were immunized by the intraperitoneal route, weekly for three weeks, and then bi-weekly with five more injections, using $1-2 \times 10^{6} \mathrm{~F} 9$ cells grown in tissue culture, harvested in EDTA, suspended in Hank's balanced salt solution, and irradiated with a cesium source (2000 rad). One week after the final immunization, the mice were inoculated with $10^{5}$ Ehrlich ascites cells to produce large amounts of antiserum (Herman and Engle, 1957). The resulting ascitic fluid had somewhat lower titers than anti-F9 antiserum; there was $50 \%$ killing of F9 cells in the microcytotoxicity test (Artzt et al., 1973) at a 1/300 dilution. Two additional anti-F9 sera were obtained from Dr. M. Edidin: (1) AS-7, a 129/J anti-F9 serum prepared as above but with F9 cells obtained from Karen Artzt, and (2) AS-9 (CBA/HN $\times 129) \mathrm{F}_{1}$ anti-F9 serum, the CBA/HN strain having low natural immunity to tumor cells. Both sera showed precipitin lines with fetal calf sera; these were removed by a 1:1 absorption with fetal calf sera. All anti-F9 sera were routinely absorbed with equal volumes of mouse spleen cells or on primitive yolk sac (PYS) tumor (No. SV 74115-230 from Dr. L. Stevens).

Rabbit anti-mouse IgG serum labeled with fluorescein isothiocyanate (FITC) was purchased from Miles Laboratories (lot No. DS302). Rabbit anti-mouse IgM serum labeled with FITC was purchased from Cappel Laboratories (lot No. 11925) and was absorbed as described for rabbit and mouse IgG. These sera were absorbed on mouse liver suspension at a ratio of 2 vols. of packed cells to 1 vol. of conjugated serum before use. Liver, spleen, or PYS tumor were finaly diced, dissociated with a No. 16 mesh screen, and brought to about 10 vols. in Dulbecco's $\left(\mathrm{Ca}^{2+}-\mathrm{Mg}^{2+}\right)$-free phosphate-buffered saline. The suspension was allowed to settle $(1 \mathrm{~g})$ for $10 \mathrm{~min}$ to remove large fragments and the cells in the supernatant were pelleted by centrifugation for $10 \mathrm{~min}$ at $500 \mathrm{~g}$. Dilutions of sera maintaining the indicated ratios of sera to cells were added to the pellet and incubated $60 \mathrm{~min}$ at $0^{\circ} \mathrm{C}$. The tissue was removed by low-speed centrifugation $(500 \mathrm{~g}$ for $10 \mathrm{~min}$ ) and the absorbed sera cleared by higher speed centrifugation $(10000 \mathrm{~g}$ for $10 \mathrm{~min})$, both at $4^{\circ} \mathrm{C}$. Sperm were prepared and counted as previously described (Betlach and Erickson, 1973), pelleted and the supernatant discarded. $100 \mu \mathrm{l}$ of the dilution of antisera used for immunofluorescence was added to the indicated number of spermatozoa and absorption continued as above. Fresh sheep red blood cells were washed twice with the above media, pelleted for $10 \mathrm{~min}$ at $800 \mathrm{~g}$, and used for absorption.

\section{Preparation and treatment of embryos}

Pre-implantation embryos were obtained from crosses of heterozygotes for lethal mutations inter se. Such crosses are expected to yield homozygous lethal embryos (Table 1). Pre-implantation embryos were flushed in Whitten's medium (Whitten, 1957) from the 


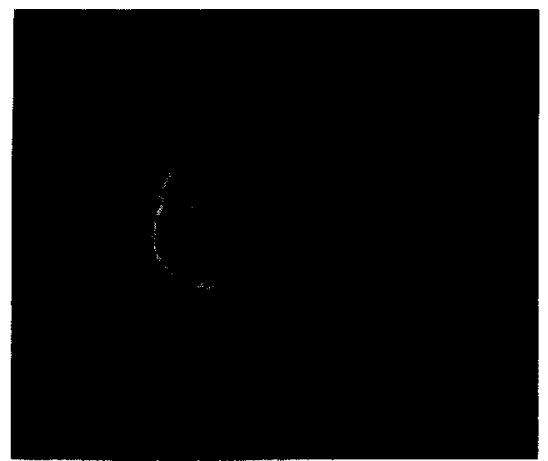

Fig. 1. Delayed morulae from $+/ t^{12} x+/ t^{12}$ cross on day $3 \frac{1}{2}$ showing positive fluorescence with antiF9 antiserum.

oviducts (on day $2 \frac{1}{2}$ ) or uteri (on day $3 \frac{1}{2}$ ) of timed pregnant females (noon of the day of finding the vaginal plug is taken as day $\frac{1}{2}$ since insemination occurs, on the average, at midnight). The zona pellucida was removed by a $10 \mathrm{~min}$ incubation with $0.25 \%$ pronase and $1 \%$ PVP in PBS and the embryos were then washed twice and allowed to 'rest' at $37^{\circ} \mathrm{C}$ for $2 \mathrm{~h}$ in Whitten's medium in the $\mathrm{CO}_{2}$ incubator. They were then incubated for $1 \mathrm{~h}$ at $4^{\circ} \mathrm{C}$ and an anti-F9 mouse serum (1/20 for the ascitic fluid, $1 / 10$ for AS-7, and 1/20 for AS-9) and rinsed through three changes of medium. This was followed by a $1 \mathrm{~h}$ incubation at $4^{\circ} \mathrm{C}$ in the FITC-rabbit anti-mouse $\operatorname{IgG}(1 ; 10)$ and four more washes before exmaination with a Zeiss epi-illumination fluorescence microscope. Controls included use of normal mouse sera at the same dilutions or no sera during the first incubation. Only cell surface staining (Fig. 1) was accepted as positive since dead cells of all kinds can be non-specifically filled with fluorescent material. All groups of pre-implantation embryos were read 'blind' with the observer not knowing what cross produced a given batch of embryos. The degree of immunofluorescence varies in embryos of the same genotype on different days and the classification of embryos as positive or negative involved a certain degree of subjectivity. Although lower dilutions of the anti-F 9 ascites serum stained a certain percentage of $+/+$ embryos, the $1 / 20$ dilution was used extensively since it was the limiting dilution yielding high percentages of positive $+/+$ embryos. We consistently found higher percentages of embryos from all crosses to be positive on day $3 \frac{1}{2}$; therefore day $3 \frac{1}{2}$ embryos were primarily studied in crosses involving the developmental lethals other than those in the $T$-region.

\section{RESULTS}

The antisera used in this study showed the reactivities, with $+/+$ embryos and spermatozoa but not with adult liver and spleen, which are expected for anti-F9 sera. As seen in Fig. 2, the reactivities with embryos of all 3 antisera used in this study were readily absorbed by spermatozoa prepared from wild-type mice. It has recently been found that the F9 cell line is not completely nullipotent and that parietal endoderm-like cells appear with low frequency (Sherman and Miller, 1978). Therefore, in many of our experiments 


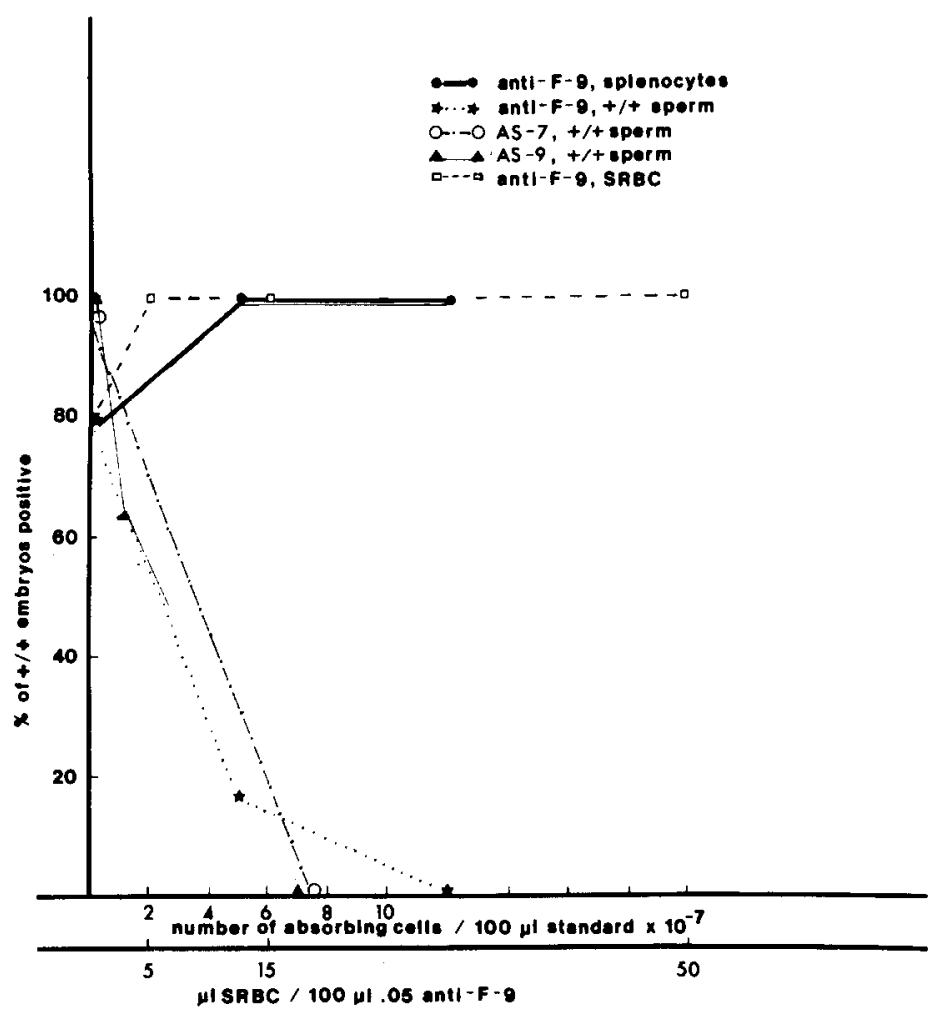

Fig. 2. Absorption of anti-F9 antisera with spermatozoa or other cells. Ordinate: percentage of wildtype embryos positive by immunofluorescence with the absorbed or control sera; abscissa: number of cells or volume of packed sheep red blood cells used for absorption.

the antisera were further absorbed with primitive yolk sac (PYS) tumor to remove these possible cross-reacting specificities. In addition, primitive yolk sac specific antigens are not known to appear on the normal blastocyst; thus a component in the antisera crossreacting with PYS should not be of concern. About equal numbers of embryos were studied with PYS-absorbed and spleen cell-absorbed anti-F9. Of 14 chi-square tests performed on the differences between the two absorptions, only one difference was statistically significant. Finally, Stern et al. (1978) and Willison and Stern (1978) have identified a Forssman-type specificity (classically present on sheep red blood cells) shared by preimplantation embryos, teratocarcinoma cells and spermatozoa. Our major antiserum's reactivity with pre-implantation embryos cannot be due to such a heterophilic component, since it could not be absorbed by sheep red blood cells (Fig. 2).

A comparison of the expression of F9 antigen on normal embryos with its expression on a number of embryos carrying lethal mutations other than those at the $T$-locus can be seen in Table 2 . Since the degree of reactivity was essentially the same whether the antiF9 sera had been absorbed with spleen cells or PYS tumor the data were pooled. All 20 embryos from $c^{\text {ch }} / c^{25 \mathrm{H}} \times c^{\text {ch }} \times c^{25 \mathrm{H}}$ litters were positive on day $3 \frac{1}{2}$. These included 15 
TABLE 2

F9 antigen expression on pre-implantation embryos from crosses involving non- $T$-region developmental lethal mutations

\begin{tabular}{|c|c|c|c|c|}
\hline \multirow[t]{2}{*}{ Cross } & \multicolumn{2}{|l|}{ Day $2 \frac{1}{2}$} & \multicolumn{2}{|l|}{ Day $3 \frac{1}{2}$} \\
\hline & $\begin{array}{l}\text { No. pos./total } \\
\text { (No. litters) }\end{array}$ & \% Positive & $\begin{array}{l}\text { No. pos./total } \\
\text { (No. litters) }\end{array}$ & $\%$ Positive \\
\hline \multicolumn{5}{|l|}{$c^{\mathrm{ch}} / c^{25 \mathrm{H}} \times c^{\mathrm{ch}} / c^{25 \mathrm{H}}$} \\
\hline $\begin{array}{l}\text { Cleavage-arrested } \\
\text { embryos } 4-8 \text { cells }\end{array}$ & & & $5 / 5 \quad(3)$ & 100 \\
\hline Blastocysts & & & $15 / 15(3)$ & 100 \\
\hline$+10 s x+10 s$ & $2 / 20(2)$ & 10 & $38 / 38(6)$ & 100 \\
\hline$c^{\mathrm{ch}} / c^{6 \mathrm{H}} \times c^{\mathrm{ch}} / c^{6 \mathrm{H}}$ & $3 / 14(1)$ & 21 & $37 / 37(3)$ & 100 \\
\hline
\end{tabular}

normal blastocysts as well as 5 embryos identified as $c^{25 \mathrm{H}}$ homozygotes because of their arrest in early cleavage (Lewis, 1978) and their striking nuclear abnormalities observed in cytological preparations made after the fluorescence studies (S. Lewis, unpublished).

The peri-implantation $O s / O s$ homozygote (Van Valen, 1966) cannot consistently be distinguished morphologically from its normal littermates on day $3 \frac{1}{2}$ of development without histological or cytological analysis. However, it is likely that this lethal homozygote also expresses F9 antigen. All 38 embryos from crosses of $O s$ heterozygotes inter se express the antigen; $1 / 4$ of these blastocysts are expected to be lethal Os/Os homozygotes $\left(\chi^{2} 38 / 4 \neq 0\right.$ is $\left.9.5, P<0.01\right)$.

In addition, we examined the expression of $\mathrm{F} 9$ antigen on $3 \frac{1}{2}$-day-old embryos homozygous for $c^{6 \mathrm{H}}$, a post-implantation lethal mutation (Lewis et al., 1976). All 37 blastocysts reacted positively with the antiserum, among which must be included $c^{6 \mathrm{H}}$ homozygotes $\left(\chi^{2} 37 / 4 \neq 0\right.$ is $\left.9.25, P<0.01\right)$. In at least one case, early post-implantation lethality is therefore not necessarily associated with a failure of expression of $\mathrm{F} 9$ antigen.

A comparison of $\mathrm{F} 9$ antigen expression in embryos from a number of crosses involving $t^{12}$ which were performed on day $3 \frac{1}{2}$ of development is shown in Table $3 .+/ t^{12} X+/ t^{12}$ crosses should produce $36 \% t^{12} / t^{12}$ progeny because of the segregation ratio currently recorded for $t^{12}$-carrying males in our colony. On day $3 \frac{1}{2}, 98 \%$ of the embryos from this cross-reacted with our ascites-derived antiserum and fluorescein labeled rabbit anti-mouse IgG (Table 3, row 1). 53\% of these $3 \frac{1}{2}$-day-old embryos were at the morula stage (there were $29 \% 3 \frac{1}{2}$-day morula in the control crosses) and these must include the $t^{12} / t^{12} \mathrm{em}$ bryos. Thus, we found no evidence for segregation of $\mathrm{F} 9$ antigen reactivity in crosses producing the $t^{12}$ homozygote at $3 \frac{1}{2}$ days of development.

There was a possible effect of the $T$-region genotype of the male on the time of appearance of $\mathrm{F} 9$ antigen in these crosses involving $t^{12}$. If the father carries $T$, an effect on the expression of F9 antigen on day $2 \frac{1}{2}$ was noted (Table 3 ). In the experimental crosses of $T / t^{12} \times T / t^{12}$ or $+/ t^{12} \times T / t^{12}$ in which $T$ was transmitted by the father, only $3 \%$ of the embryos were positive on day $2 \frac{1}{2}$ (Table 3 , row 2 ), while $38 \%$ were positive 


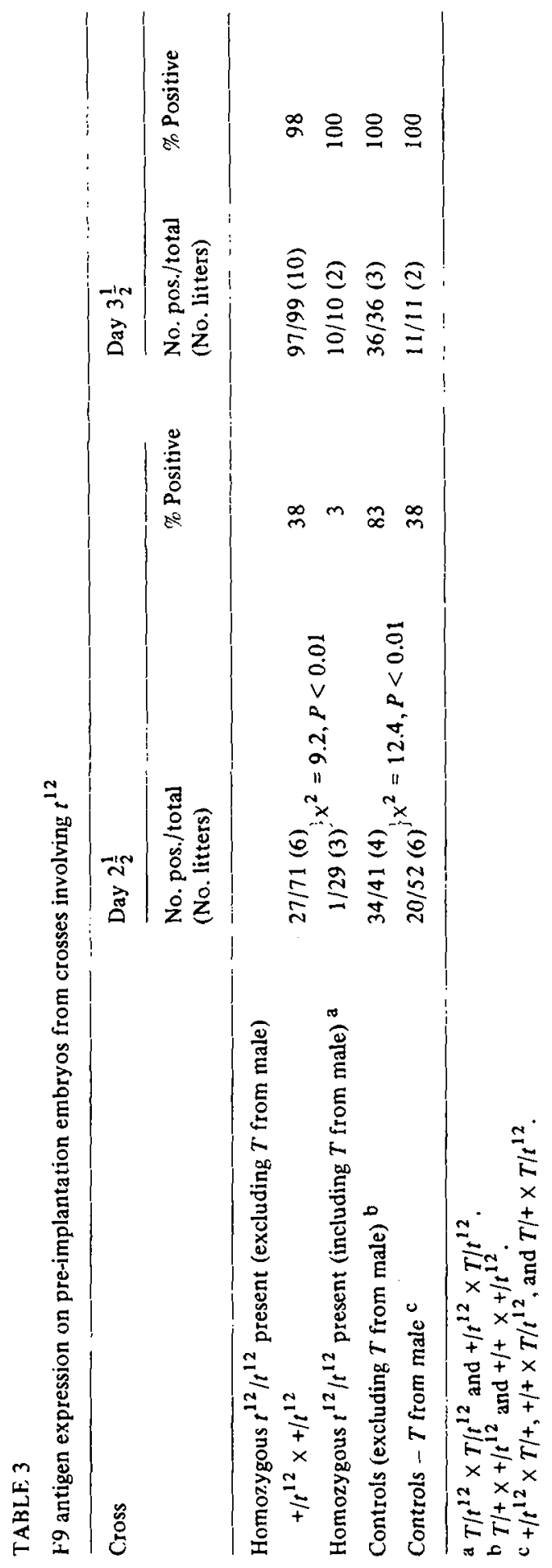


TABLE 4

F9 antigen expression on $3 \frac{1}{2}$-day embryos using alternative antisera

\begin{tabular}{|c|c|c|c|c|c|c|}
\hline \multirow[t]{2}{*}{ Antisera } & \multirow{2}{*}{$\begin{array}{l}\text { Working } \\
\text { dilution }\end{array}$} & \multirow[t]{2}{*}{ Cross } & \multirow{2}{*}{$\begin{array}{l}\text { No. } \\
\text { litters }\end{array}$} & \multicolumn{2}{|c|}{ No. pos./total } & \multirow[t]{2}{*}{$\%$ Positive } \\
\hline & & & & Morulae & $\begin{array}{l}\text { Blasto- } \\
\text { cysts }\end{array}$ & \\
\hline AS-7 (129 anti-F9) & $\begin{array}{l}1 / 10 \\
1 / 10\end{array}$ & $\begin{array}{l}+/+x+/+ \\
+/ t^{12} x+/ t^{12}\end{array}$ & $\begin{array}{l}3 \\
5\end{array}$ & $\begin{array}{l}10 / 10 \\
15 / 15\end{array}$ & $\begin{array}{r}14 / 15 \\
5 / 13\end{array}$ & $\begin{array}{l}96 \\
71\end{array}$ \\
\hline \multirow[t]{2}{*}{$\begin{array}{l}\text { AS-9 (CBA/HN } \times \\
129 / \text { JF anti-F9) }\end{array}$} & $1 / 20$ & $\begin{array}{l}+/+x+/+ \\
T /+x+/ t^{12}\end{array}$ & 3 & $12 / 15$ & $18 / 21$ & 83 \\
\hline & $1 / 20$ & $+/ t^{12} x+/ t^{12}$ & 3 & $22 / 30$ & $9 / 15$ & 64 \\
\hline \multirow[t]{2}{*}{$\begin{array}{l}\text { Anti-F9 with anti- } \\
\text { mouse IgM as } \\
\text { second layer }\end{array}$} & $1 / 20,1 / 10^{a}$ & $+1+x+1+$ & 1 & $6 / 6$ & - & 100 \\
\hline & $1 / 20,1 / 10^{a}$ & $+/ t^{12} x+/ t^{12}$ & 1 & $6 / 7$ & $9 / 9$ & 94 \\
\hline
\end{tabular}

a Anti-F9 was $1 / 20$, anti-mouse IgM was $1 / 10$.

when the father did not carry $T$. This apparent effect of a $T$-carrying father was also seen in control crosses where no $t^{12} / t^{12}$ embryos were involved. $83 \%$ of embryos whose father did not transmit $T$ were positive on days $2 \frac{1}{2}$ (Table 3 , row 3 ) while $38 \%$ of embryos were positive on day $2 \frac{1}{2}$ when $T$ was inherited from the father (Table 3 , row 4 ). Thus it appears that $T$ carried by the father, but not the mother, delays expression of the F9 antigen.

The reactivity of antisera from other sources was also studied on $t^{12} / t^{12}$ embryos from the same crosses (Table 4). Both AS-7 and AS-9 gave lower percentages of positively reacting embryos in crosses where $t^{12}$ homozygotes would be present than in control crosses but the deficiency was as severe, or more so, for blastocysts (among which there cannot be any $t^{12} / t^{12}$ embryos) as for morulae (which include both $t^{12} / t^{12}$ and normally delayed embryos). Since a monoclonal antibody to the F9 teratocarcinoma is IgM (Solter and Knowles, 1978), we have also tested the reactivity of our major antiserum using antiIgM as the second reagent. The results were no different than those found when using anti-IgG in both $+/ t^{12} X+/ t^{12}$ and control crosses. Thus, two other anti-F9 antisera and a different second antibody failed to provide evidence for the absence of $\mathrm{F} 9$ antigen in $t^{12} / t^{12}$ embryos.

We also tested reactivity of our anti-F9 serum with two other $T$-region mutants. Our studies of embryos from crosses involving $t^{\mathrm{w} 5}$, a lethal at the egg cylinder stage, where nearly half the embryos should be homozygous $t^{\mathrm{w} 5}$ because of the high segregation distortion of $t^{\mathrm{w5} 5}$, show $65 \%$ reactivity with the anti-F9 antiserum. This represents a $29 \%$ deficiency compared to the controls involving the $t^{\mathrm{w} 5}$ stock.

$T^{\mathrm{Or} 1}$ is a deletion in the $T$-region which extends for at least 3 centimorgans from $T$ to quaking (Erickson et al., 1978). As seen in Table 5, 81\% of 36 embryos from crosses expected to produce $25 \% T^{\text {Or } 1} / T^{\text {Or } 1}$ were positive on day $3 \frac{1}{2}$. This is a $19 \%$ deficiency from controls involving $T^{\text {Or } 1}$ stock. Thus, $T^{\text {Or } 1}$ homozygotes, expected as $25 \%$ of the progeny, may not express $\mathrm{F} 9$ antigen on day $3 \frac{1}{2}$ of development. 


\section{TABLE 5}

F9 antigen expression on pre-implantation embryos from crosses involving post-implantation $T$ region mutants ${ }^{\text {a }}$

\begin{tabular}{|c|c|c|c|}
\hline Cross & $\begin{array}{l}\text { Day } 3 \frac{1}{2} \\
\text { No. pos./total } \\
\text { (No. litters) }\end{array}$ & $\begin{array}{l}\text { Total } \\
\% \text { positive }\end{array}$ & $\begin{array}{l}\text { Probability } \\
\text { of difference }\end{array}$ \\
\hline \multirow{2}{*}{$\begin{array}{l}\text { Homozygous } t^{\mathrm{w} 5} \text { present } \\
\qquad\left(t^{\mathrm{w} 5} /+\times t^{\mathrm{w} 5} / T, t^{\mathrm{w} 5} /+\times t^{\mathrm{w} 5} /+\right) \\
\text { Control }\left(+/ t^{\mathrm{w} 5} \times T /+\right)\end{array}$} & $23 / 35(6)$ & \multirow{2}{*}{${ }_{94}^{65} x^{2}=3.86$} & \multirow[b]{2}{*}{$P<0.05$} \\
\hline & $30 / 32(2)$ & & \\
\hline $\begin{array}{l}\text { Homozygous } T^{0 \mathrm{r} 1} \text { present } \\
\qquad\left(+/ T^{\text {Or } 1} \times+/ T^{0 \mathrm{r} 1}\right)\end{array}$ & $29 / 36(3)$ & \multirow{2}{*}{${ }_{100}^{81} x^{2}=1.5$} & \multirow{2}{*}{$P>0.1$} \\
\hline Control $\left(+/+X+/ T^{0 r 1}\right)$ & $30 / 30(2)$ & & \\
\hline
\end{tabular}

${ }^{a}$ Anti-F9 absorbed on PYS tumor was used.

\section{DISCUSSION}

The results of this study clearly show a normal frequency of F9 antigen expression on embryos homozygous for mutant genes causing embryonic lethality at several stages of development: (1) cleavage $-c^{25 \mathrm{H}}$, (2) morula $-t^{\mathbf{1 2}}$, (3) peri-implantation - Os, and (4) egg cylinder $-c^{6 \mathbf{H}}$. We were not able to establish clearly whether embryos homozygous for two other $T$-region variants, $T^{\mathrm{Or} 1}$ and $t^{\mathrm{w} 5}$, showed normal expression of the F9 antigen.

The reasons for the discrepancy between our results on $t^{12}$ homozygous embryos and those of Kemler et al. (1976) are not clear. We used 3 different F9 antisera, all with the same apparent specificities as theirs. Hillman and Hillman (1975) have shown in studies with transmission electron microscopy that $t^{\mathrm{w} 32} / t^{\mathrm{w} 32}$ embryos are distinguishable from $t^{12} / t^{12}$ embryos, even though $t^{12}$ and $t^{\mathrm{w} 32}$ are in the same complementation group. Although initially referred to as $t^{12}$, the Pasteur group has always used $t^{\mathrm{w} 32}$ whereas our studies were carried out with $t^{\mathbf{1 2}}$. A possible difference of alleles or minor differences in technique could be the explanation for the discrepancy. However, Marticorena et al. (1978) consistently found no differences in the reactivity of embryos homozygous for $t^{\mathrm{w} 32}$ and $t^{12}$ with anti-F9. Dewey et al. (1977) have recently reported that the antigen(s) determined by an antiserum against testicular teratocarcinoma embryoid bodies was present on $t^{12} / t^{12}$ embryos ( $t^{12}$ belongs to the same complementation group as $t^{\mathrm{w} 32}$ ) but their sera had differences in specificity compared to anti-F9 as it did not cross-react with sperm.

It is interesting to speculate whether the $T$-region controls antigens. In a preliminary communication in 1949, Caspari and Dalton presented data suggesting that an antigen present in soluble extracts of testes was controlled by $T$. However, antisera which had been raised in rabbits and the putative $T$-specific antigen were apparently not studied further. In 1957, Gluecksohn-Waelsch proposed that $t$-alleles might alter cell surface specificities, and in 1971 Gluecksohn-Waelsch and Erickson refined the immunological hypothesis for $T$-region effects to state that cell surface antigens present on sperm and embryos 
might be controlled by this region. Evidence for $T$-region determined antigens on sperm has been presented from one laboratory (Bennett et al., 1972; Yanagisawa et al., 1974; Artzt and Bennett, 1977) but other laboratories have not been able to confirm these findings. In one extensive report, $T$-region determined antigens could not be found on spermatozoa by numerous antiglobulin tests (Goodfellow et al., 1979). However, this is not the immunological test used in the positive reports, which utilized a direct sperm cytotoxicity test. Thus, further negative results with a sperm cytotoxicity test are more important (Gable et al., 1979). It is currently a moot point whether there are $T$-region antigens expressed on spermatozoa.

A second approach has related teratocarcinoma antigens to the $T$-region. The evidence in favor of the F9 antigen being determined by a structural gene at the wild-type allele of the $t^{12}$ mutation has been reviewed above. We have not been able to confirm that part of the evidence which relates to segregation of F9 antigen in embryos from crosses involving $t^{12}$. Thus, there is no consistent evidence that teratocarcinoma antigens are coded by genes in the $T$-region.

On the other hand, any large chromosomal region could include genes for several cell surface proteins. Recent data (Erickson et al., 1978) which indicate that the $T$-region may extend for six centimorgans on chromosome 17 encourages one to believe that more than one antigen could be determined in this region. Loci coding for minor histocompatibility antigens are found with high density near the $\mathrm{H}-2$ region (Flaherty, 1975; Artzt et al., 1977) which is only 5 centimorgans from the tufted region to which embryonic lethal effects of $t$-alleles seem to map (Lyon and Bechtol, 1977). Furthermore, studies in manmouse somatic hybrids which retain only one heterospecific chromosome have shown that each such hybrid contains cell surface antigens coded for by the heterospecific chromosome (Kao et al., 1977; Dorman et al., 1978). Thus, it would not be surprising if some further refinements in technique or approach will allow the detection of cell surface antigens coded for by genes in the $T$-region. It will then be necessary to determine the possible relationship between such antigens and the many interesting biological properties of the $T$-region.

\section{ACKNOWLEDGEMENTS}

It is a pleasure to acknowledge gifts of strains of mice by Dr. W.F. Dove, Dr. S. Gluecksohn-Waelsch, Dr. Jean-Louis Guenet and Dr. R. Pedersen. Dr. L. Stevens kindly provided the PYS tumor. Dr. Marie-Helene Buc-Caron kindly helped prepare the ascitic anti-F9 antiserum while Drs. Michael Edidin and Craig Hammerberg thoughtfully provided the AS-7 and AS-9 anti-F9 antisera. Mrs. Rena Jones provided excellent secretarial assistance. This work has been supported by grant GM-15419 from N.I.H. and an N.I.H. National Service Award to S.L.

\section{REFERENCES}

Artzt, K. and Bennett, D. (1977) Serological analysis of sperm of antigenically cross-reacting $T / t$ haplotypes and their recombinants. Immunogenetics 5, 97-107.

Artzt, K., Bennett, D. and Jacob, F. (1974) Primitive teratocarcinoma cells express a differentiation antigen specified by a gene at the T-locus in the mouse. Proc. Natl. Acad. Sci. U.S.A. 71, 811-814. 
Artzt, K., Dubois, P., Bennett, D., Condamine, H., Babinet, C. and Jacob, F. (1973) Surface antigens common to mouse cleavage embryos and primitive teratocarcinoma cells in culture. Proc. Natl. Acad. Sci. U.S.A. 70, 2988-2992.

Artzt, K., Hamburger, L. and Flaherty, L. (1977) H-39, a Histocompatibility locus closely linked to the $T / \mathrm{t}$ complex. Immunogenetics $5,477-480$.

Bennett, D., Goldberg, E., Dunn, L.C. and Boyse, E.A. (1972) Serological detection of a cell-surface antigen specified by the $T$ (Brachyury) mutant gene in the house mouse. Proc. Natl. Acad. Sci. U.S.A. $69,2076-2080$.

Betlach, C.J. and Erickson, R.P. (1973) A unique RNA species from maturing mouse spermatozoa. Nature (London) 242, 114-115.

Caspari, E. and Dalton, H.C. (1949) Genic action. Carnegie Institution of Washington Year Book No. $48,188-201$.

Dewey, M.J., Gearhart, J.D. and Mintz, B. (1977) Cell surface antigens of totipotent mouse teratocarcinoma cells grown in vitro: their relation to embryo, adult, and tumor antigens. Dev. Biol. 55, $359-377$.

Dorman, B.P., Shimizu, N. and Ruddle, F.H. (1978) Genetic analysis of the human cell surface: Antigenic marker for the human X chromosome in human-mouse hybrids. Proc. Natl. Acad. Sci. U.S.A. $75,2363-2367$.

Edidin, M., Patthey, H.L., McGuire, E.J. and Sheffield, W.D. (1971) An antiserum to 'embryoid body' tumor cells that reacts with normal mouse embryos. In Embryonic and Fetal Antigens in Cancer (Anderson, N.G. and Coggin, T.H., eds.), Technical Information Bulletin, pp. 239-247. Atomic Energy Commission, Washington, D.C.

Erickson, R.P., Lewis, S.E. and Slusser, K.S. (1978) Deletion mapping of the tcomplex of chromosome 17 of the mouse. Nature (London) 274, 163-164.

Flaherty, L. (1975) H-33 - a histocompatibility locus to the left of the H-2 complex. Immunogenetics 2, 325-329.

Gable, R.J., Levinson, J.R., McDevitt, H.O. and Goodfellow, P.N. (1979) Assay for antibody mediated cytotoxicity of mouse spermatozoa by ${ }^{86}$ rubidium release. Tissue Antigens $13,177-185$.

Gluecksohn-Waelsch, S. (1957) The effects of maternal immunization against organ tissues on embryonic differentiation in the mouse. J. Embryol. Exp. Morphol. 5, 83-92.

Gluecksohn-Waelsch, S. and Erickson, R.P. (1971) Cellular membranes: A possible link between H-2 and T-locus effects. In Immunogenetics of the H-2 System (Lengerová, A. and Vojtiskova, M., eds.), pp. 120-122. Karger, Basel.

Goodfellow, P.N., Levinson, J.R., Gable, R.J. and McDevitt, H.O. (1979) Analysis of anti-sperm sera for $\mathrm{T} / \mathrm{t}$ locus-specific antibody. J. Reprod. Immunol. 1, 11-21.

Herman, Jr., E.C. and Engle, C. (1957) Tumor cell-induced ascites fluid as a source of viral antibodies. Proc. Soc. Exp. Biol. Med. 98, 257-261.

Hillman, N. and Hillman, R. (1975) Ultrastructural studies of $\mathrm{t}^{\mathrm{w} 32} / \mathrm{t}^{\mathrm{w} 32}$ mouse embryos. J. Embryol. Exp. Morphol. 33, 685-695.

Hood, L., Huang, H.V. and Dryer, W.J. (1977) The area-code hypothesis: the immune system provides clues to understanding the genetic and molecular basis of cell recognition during development. J. Supramol. Struct. 7, 407-435.

Kao, F., Jones, C. and Puck, T. (1977) Regional mapping on human chromosome 11 of five loci: Three human cell surface antigen markers, LDH-A and ACP-2. Am. J. Hum. Genet. 29, 60A (abstract).

Kemler, R., Babinet, C., Condamine, H., Gachelin, G., Guenet, J.L. and Jacob, F. (1976) Embryonal carcinoma antigen and the T/t locus of the mouse. Proc. Natl. Acad. Sci. U.S.A. 73, 4080-4084.

Lewis, S.E. (1978) Developmental analysis of lethal effects of homozygosity for the $\mathrm{c}^{25 \mathrm{H}}$ deletion in the mouse. Dev. Biol. 65, 553-557.

Lewis, S.E., Turchin, H.A. and Gluecksohn-Waelsch, S. (1976) The developmental analysis of an embryonic lethal $\left(\mathrm{c}^{6 \mathrm{H}}\right)$ in the mouse. J. Embryol. Exp. Morphol. 36, 363-371.

Lyon, M.F. and Bechtol, K.B. (1977) Derivation of mutant t-haplotypes of the mouse by presumed duplication or deletion. Genet. Res. (London) 30,63-76. 
Marticorena, P., Artzt, K. and Bennett, D. (1978) Relationship of F9 antigen and genes of the T/t complex. Immunogenetics 7, 337-347.

Sherman, M.I. and Miller, R.A. (1978) F9 embryonal carcinoma cells can differentiate into endodermlike cells. Dev. Biol. 63, 27-34.

Solter, D. and Knowles, B.B. (1978) Monoclonal antibody defining a stage-specific mouse embryonic antigen (SSEA-1). Proc. Natl. Acad. Sci. U.S.A. 75, 5565-5569.

Stern, P.L., Willison, K.R., Lennox, E., Galfrè, G., Milstein, S., Secher, D. and Zeigler, A. (1978) Monoclonal antibodies as probes for differentiation and tumor-associated antigens: a Forssman specificity on teratocarcinoma stem cells. Cell 14, 775-783.

Van Valen, P. (1966) Oligosyndactylism, an early embryonic lethal in the mouse. J. Embryol. Exp. Morphol. 15, 119-124.

Whitten, W.K. (1957) Culture of tubal ora. Nature (London) 179, 1081-1082.

Willinson, K.R. and Stern, P.L. (1978) Expression of a Forssman antigenic specificity in the preimplantation mouse embryo. Cell 14, 785-793.

Yanagisawa, K., Bennett, D., Boyse, E.A., Dunn, L.C. and Dimeo, A. (1974) Serological identification of sperm antigens specified by lethal t-alleles in the mouse. Immunogenetics 1, 57-67. 